\title{
Considering Authority and Authorship in Technological Contexts in a Brazilian School
}

\author{
Viviane Cabral Bengezen and M. Shaun Murphy
}

\begin{abstract}
In this narrative inquiry, we inquired into the experiences of Everton and Lowise, two grade 6 English as a Foreign Language students in Brazil, using digital technologies and authoring their texts, in English. In the areas of Applied Linguistics and Education, we consider discussions about the writing process in English and the possibilities of working with genres to teach and learn English through digital technologies. The research participants lived and told stories of freedom, singularity, and responsibility, becoming authors when they left their signature on the professional knowledge landscape of school.
\end{abstract}

\section{Situating the Inquiry}

We understand that the dominant story of education is generally marked with stories of standardized tests, oppression, repetition, copies, reproduction, and failure, all over the world. However, there have been many individual stories that show it is possible to make a difference, develop collaborative work, and privilege multiple perspectives. We share in this paper the stories to live by ${ }^{1}$ (Clandinin \& Connelly, 1995) and experiences of a Brazilian teacher and two of her grade 6 students who became authors in a foreign language, using digital technologies. Connelly and Clandinin (2006) wrote,

People shape their daily lives by stories of who they and others are and as they interpret their past in terms of these stories. Story, in the current idiom, is a portal through which a person enters the world and by which their experience of the world is interpreted and made personally meaningful. Narrative inquiry, the study of experience as story, then, is first and foremost a way of thinking about experience. Narrative inquiry as a methodology entails a view of the phenomenon. To use narrative inquiry methodology is to adopt a particular view of experience as phenomenon under study. (p. 375)

Employing a narrative inquiry (Clandinin \& Connelly, 2000, 2011) methodology, we drew on the narratives of Viviane, who was an English as a Foreign Language (EFL) teacher in Brazil, and two grade 6 students, Everton and Lowise. Shaun joined Viviane as a coresearcher alongside her during the research and her graduate studies while in Brazil and after. From 2014 to 2017, Viviane narratively engaged with the youth, seeking to understand who they were, and who they were becoming on the school landscape, focusing on authorship and digital technology at school. Attending to how Viviane, Everton, and Lowise shaped their daily lives in school, we, the authors of this paper, sought to understand how they interpreted the world "and made [it] personally meaningful" (Connelly \& Clandinin, 2006), and what that meant for us as teachers using digital technology. 
In 2014, 126 grade 6 students, who had EFL classes twice a week with Viviane, produced texts of diverse genres in English, and had their texts published in an online book (Bengezen, 2016). In this narrative inquiry, we focused on the individual stories to live by of Everton and Lowise while they authored texts and their lives on the landscape of a public school in Brazil. We decided to tell and retell the stories of these two children, specifically, because of the way they used technology in different spaces in the curriculum, living and telling stories that were not about failure-despite the obstacles they faced. Everton, Lowise, and their parents have agreed to reveal their real names in order to honour who they are and recognize their role in the co-composition of this work. However, the real name of the school has been changed to a pseudonym because it is not the focus of this inquiry.

\section{Issues of Methodology and Method}

We came to understand Viviane's practice and the use of digital technologies as narratively constructed. As narrative inquirers, we see narrative as the method and phenomenon (Connelly \& Clandinin, 1990). We are interested in the experiences people live and tell; we understand experience and we study it, narratively. Narrative inquiry is situated in a Deweyan ontology of experience and the,

regulative ideal for inquiry is not to generate an exclusively faithful representation of a reality independent of the knower. The regulative ideal for inquiry is to generate a new relation between a human being and her environment-her life, community, world-one that 'makes possible a new way of dealing with them, and thus eventually creates a new kind of experienced objects, not more real than those which preceded but more significant, and less overwhelming and oppressive' (Dewey, 1981, p. 175) [...] In this pragmatic view of knowledge, our representations arise from experience and must return to that experience for their validation (Clandinin \& Rosiek, 2007, p. 39).

Clandinin and Murphy (2009) noted, "[t]hree features of a Deweyan ontology of experience are well suited for framing narrative research: emphasis on the social dimension of inquiry, temporality of knowledge generation, and continuity that is not merely perceptual but ontological" (p. 599).

Understanding experience narratively means that we considered experience in relation to the metaphorical three-dimensional narrative inquiry space (Clandinin \& Connelly, 2000) with place, temporal, and social dimensions. This is understood "with temporality along one dimension, the personal and the social along a second dimension, and place along the third" (p. 50). Within this inquiry space we were able to see threads of experience woven across Everton, Lowise, and Viviane's stories to live by.

Narrative threads (Clandinin, 2013) attend to experience across lives. Rather than reduce experience to categories or themes, the concept of threads understands the complexity of experience in the entirety of a life. Minh-ha (1989) wrote, "[d]espite our desperate, eternal attempt to separate, contain, and mend, categories always leak" (p. 94). For this reason, we resist the temptation to categorize experience and, rather, consider that experience can be traced threadlike across the weaving of a life. Following the thinking of Clarke (2016), "[a]s researchers who struggle to separate our own identities into categories, we recognize the inappropriateness of trying to do the same in our exploration of the [stories to live by] 
of our research participants" (p. 22). Therefore, we consider the threads that move across categories in our research.

We composed field texts during the 2014 school year, comprising field notes, reflexive journals, school attendance registers, class materials (handouts and assessments) produced by the teacher, Viviane, material (handwritten or posted on a virtual platform-comic strips, drawings, animations, T-shirt slogans, lyrics, word clouds, avatars, and poems) produced by the youth, WhatsApp messages, Facebook conversations, and digital photographs.

Moving from field texts as we composed this final research text, we wrote interim research texts, drawing attention to moments and places of tensions, and moments when our stories were being shifted. Considering the metaphorical three-dimensional narrative inquiry space (Clandinin \& Connelly, 2000), we identified the narrative threads which wove through the stories we lived and told on the landscape of school. From our attention to these threads we co-composed this relational research text.

Considering the relational aspect of narrative inquiry, within a view of knowledge as personal, embodied, narrative, and shaped through their lived experiences (Bruner, 1986; Clandinin, 2013; Clandinin \& Connelly, 1995; Clandinin et al., 2006; Connelly \& Clandinin, 1988), we understood that through a collaborative kind of research such as narrative inquiry, it would bring us into school, opening up new questions about our responsibilities as researchers, and the ways our research texts attended to the participants' lives. We began this research with wonders about composing a story to live by: How is authorship taken up in the lives of youth in digital contexts and what do these experiences with authorship tell us?

In the sections that follow we introduce Everton in order to situate our thinking about how technology can support identity making in schools. We move into a discussion about genre work related to technology. We then focus on the experiences of Lowise and how technology helped her to foster a connection to school. The next section includes a discussion about Everton and Lowise together before our final conclusion. We selected the two youth to be the focus of this study in order to inquire more deeply into their experience. We were particularly interested in Everton and Lowise because their work supported our research into how technology can support authorship and the creation of a story to live by in educative ways (Dewey, 1938).

\section{A Thread in Everton's Secret Stories}

First, we introduce Everton, by drawing on field texts that show our coming to know him as a youth who began grade 6 for the second time. Following are some of the ways Everton described himself to his teacher, Viviane, and his classmates. 


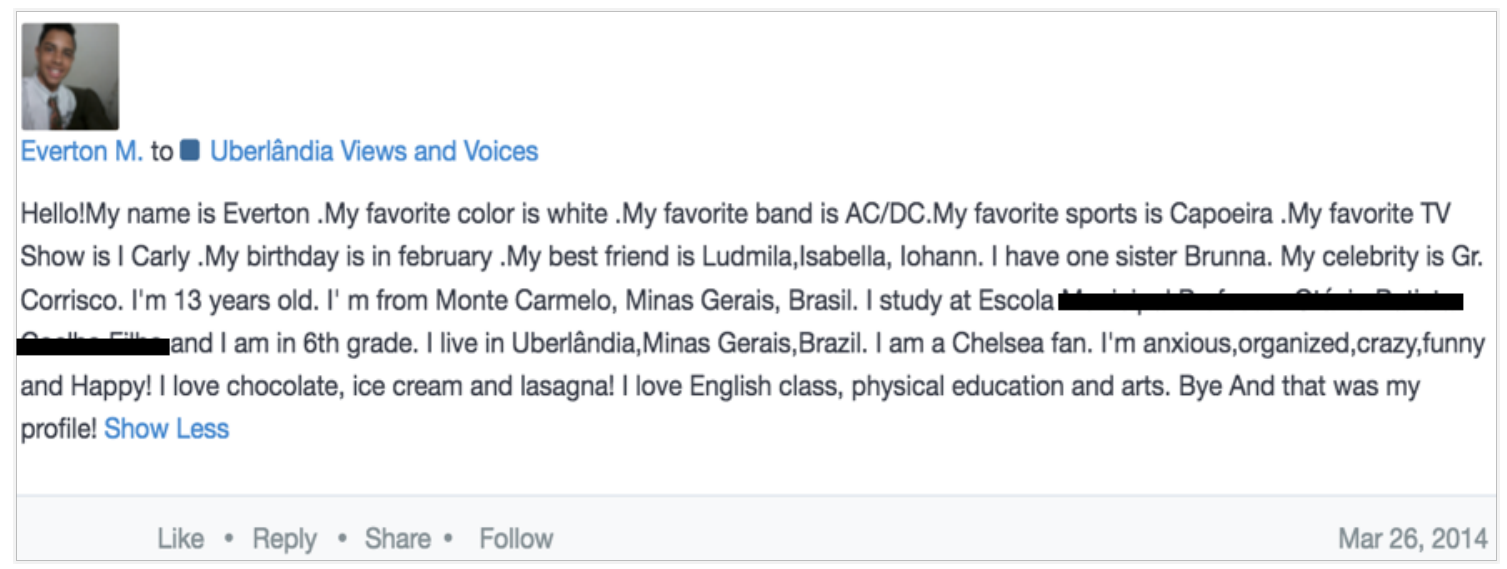

Fig. 1: Everton's profile shared on Edmodo, March 26, 2014

This profile that Everton shared on Edmodo, a virtual platform used by his teacher Viviane to communicate with her grade 6 students, helped us to narratively understand the authorship experiences of youth in schools when they use digital technology. We position ourselves in a tradition of curriculum studies grounded in Dewey's (1938) concept of experience and Schwab's (1973) concepts of curriculum commonplaces. We were interested in understanding the stories of authorship that the youth told in schools in relation to Schwab's curriculum commonplaces of learner, subject matter, teacher, and milieu, and Dewey's (1938) criteria of experience understood by the terms of continuity, interaction, and situation.

In Brazil, most studies related to authorship were developed in Portuguese teaching and learning contexts, based on the theoretical assumptions of Foucauldian discourse analysis, among other French post-structuralist perspectives (Fernandes, 2016; Possenti, 2016; Brait, 2016). In education and applied linguistics, the focus has been on the product accomplished by the teacher or student, with no interest in how individuals felt while writing or what is the process of producing texts in schools and universities. Almost all the investigations focused on the authorship of final texts, but not the experiences of producing those texts.

In this work, however, our focus was not on the final texts produced by the youth. Rather, we were interested in the process, and in narratively understanding the stories of authorship lived and told as one way of inquiring into the youth's stories to live by. We understand authorship related to voice and signature (Clandinin \& Connelly, 2000), that is, the production of texts with the mark of the author's identity, their story to live by.

Drawing on the work of Morris (2001), we contemplated Everton's experiences,

At the beginning of 2014, when Viviane, Everton's teacher, entered one of her grade 6 classrooms and saw Everton, she was amazed, "What are you doing here, Everton? You are supposed to be in grade 7, aren't you? Which subject did you fail?" He responded, "Only Portuguese, teacher!" (Field notes, February 12, 2014) 
Everton's response left Viviane even more surprised, since they were Brazilian, and Portuguese was their first language. Viviane was and had been Everton's teacher of English as a Foreign Language, referred to as English classes. The school system in which Viviane worked was in a city in central Brazil. From grades 6 to 9, the students had one teacher for each subject (Portuguese, Math, Natural Sciences, History, Geography, English as a Foreign Language, Physical Education, and Arts). In grade 6, if a student failed just one subject, they had to do the whole year over again; physical education and arts could not fail a student. Considering Everton's experience (Morris, 2001), we wondered about how his story to live by was "mis-educatively" (Dewey, 1938) shaped by this experience of repeating the grade, and the ways he composed a forward-looking story in relation to his work with Viviane in technological contexts.

Everton told us how he felt in relation to different spaces on the school landscape, and in relation to different teachers:

English classes, for me, were always a good thing, where not only were we writing things that the teacher wanted, but things we wanted. In English classes with teacher Viviane, we performed several dynamics, went to the [computer] lab frequently, and wrote various texts where we could choose what to write. We had more freedom to write. We could show and express what we felt. (Field text: WhatsApp conversation between Viviane and Everton, May 13, 2016)

As we read Viviane's field notes, conversations with Everton, Everton's texts, and told remembered stories of the experiences at school, in Brazil, we further wondered about the space of the computer lab, the authorship of youth, their signature of personhood on the texts they produced, the relation between language and identity, and our responsibility, as educators, in listening to their voice. Viviane's English classes took place in the classroom as well as in the computer lab. Everton had a lot of fun with computers and felt good about being able to help his classmates. They were able to communicate using a virtual platform, Edmodo. The first English texts read by Everton were Viviane and Shaun's profiles. Since Viviane's EFL pedagogy was based on genres (Cristóvão \& Beato-Canato, 2016), and since the first activity the grade 6 students did was to write their own profiles in English, they needed to read many authentic samples of each genre. Therefore, they began by reading Viviane's and Shaun's (Shaun had joined the group on Edmodo as a foreign participant. The Brazilian students were excited to have a Canadian who could read their texts).

Everton uses technology in supportive ways. In addition to Viviane and Shaun's profile, Everton had read other people's profiles during the previous year. Viviane's students were exposed to seven texts representing the profile genre. They identified the cultural context in which those texts function, what social purposes they served, and how their structures reflected their functions. Viviane and her students engaged in a study of the genre profile, negotiating, developing content knowledge, talking, note-taking, observing, discussing, and then working to collaboratively produce a profile (a version of the genre). After all this work, Everton was able to construct a version of his own profile, drafting the text, talking to his teacher and classmates, editing, and publishing his text on Edmodo. 
Everton's classmates used to ask him for help because he was more familiar with digital technologies and had more experience, ability, and skills with the activities on the computer than in the notebook:

I think I felt more valued in English classes, because Viviane took us to the computer lab a lot. I loved creating an avatar that spoke English. I liked to finish my assignments soon so I could get up from my chair and walk around the computer lab to help my classmates who were unable to develop the activities proposed in English classes. On Edmodo, as soon as I published my avatar, one of my classmates asked for my help. I liked this position of who can do things and be popular in school. However, I think the other teachers did not see me like this, as some students saw me, or how Viviane saw me. In general, I felt a bit unsuccessful at school, having repeated years. It seems that everything I knew was not good for school. (Field text: WhatsApp conversation between Viviane and Everton, May 14, 2016)

Although Everton was doing grade 6 for the second time, he did not feel uncomfortable all the time, only in some spaces, with specific teachers. He saw himself as a knower, however "everything" he knew

"was not good for school." As we listened to Everton tell his stories, we could hear how hard it must have been for him to still attend to all the subjects in grade 6, for a whole school year again, being judged by others. On the other hand, in some spaces at school, such as the English classes, Everton felt empowered as "a person who can do things and be popular in school." He continued,

for me, writing my first English text was a fantastic thing, because it was an easy thing. I imagined that would be impossible, but the classes were showing me that I was able to do it. The profile I wrote in English helped me a lot, and then I started to write some texts in English. It made me want to write, I really like writing songs nowadays. (Field text: WhatsApp conversation between Viviane and Everton, May 14, 2016)

As we listened more to Everton tell his stories, we could hear how he liked to write and observed how he positioned himself as a writer and a knower. Everton was not afraid to assert himself in the EFL classes. Consequently, he took a leading role in the class, which we also noticed in his experiences writing a profile, helping classmates, and using the computer. We became interested in the ways Everton positioned himself and how he expressed his stories to live by in school.

This was possible because technology was used in new ways and Everton could use the computer and the Internet to learn English by reading and writing authentic texts, which are part of the digital technology world. Technology opened up a space for Everton in his work. There was an interplay here between Everton, Viviane, and technology. Technology was part of this interwoven identity-making place for Everton and, along with the work in the various genres, supported him in his learning and in his identity making (Clandinin et al., 2006).

\section{Threads of Connection: Lowise Builds a Bridge Between the School and Hospital}

The second participant, Lowise ${ }^{2}$ (in memoriam), was a student who had chosen to author a T-shirt slogan at the end of the school year. In March 2014, Lowise posted her own profile on Edmodo in English. It is important to underscore that Lowise was not proficient in English, nor had she any help at home related to English. She established a relationship with her teacher, Viviane, through the Internet. Lowise followed the instructions, read the profiles that were available on the Internet, and wrote her own: 
Lowise M. a Uberlândia Views and Voices

My name is Lowise. I'm 10 years old. I am from Uberlândia and I live in Uberlândia. I have two brother, Ewerton and Mathews. I am single girl of the my family. I'm a student at Escola Municipal do ballet and my favorite color is lilac. My best friend and Débora. I am beautiful, inteligent, and polite. My mother is Larissa and my father is Wanderley.

Descurtir (1) - Responder • Compartilhar 23 março, 2

Fig. 2: Lowise's profile on Edmodo

After producing this text, she created an English-speaking avatar using the site Voki. She chose the character, voice, and accent, typed the text in English, and shared her product on the Internet. Lowise also had Skype conversations with Viviane, and was assessed, even though she was mostly in a hospital room, during her cancer treatment. Before composing the research texts where Lowise was the participant, Viviane had long conversations with her mother, Larissa, who thought it was important to tell Lowise's story and the struggle to create opportunities for the authorship of children who are in a hospital for treatment. In 2015, when Viviane was no longer Lowise's teacher, the school decided to fail her, arguing that Lowise was in hospital and not capable of going to grade 7 . Some months later, she died.

After Lowise passed away, Viviane had an appointment with Larissa. It was essential for Viviane to know whether or not Larissa wanted to tell Lowise's story. Larissa would be the one to decide if her daughter's story would be published, despite the pain caused by remembering the experiences Lowise had lived when she was Viviane's student. In Larissa's home, Viviane listened to Lowise's story among many tears, smiles, hugs, surprises, and emotions. It was the first time Viviane saw the story from Lowise's mother's point of view, and Viviane was surprised, because she didn't know how much Larissa had fought for Lowise's right to learn. While Lowise was in the hospital, it had been extremely difficult for Larissa to keep her daughter connected to her classes and teachers, so much so that at one point Larissa thought she was losing her mind.

In 2014, Viviane put into practice the ideas Larissa had about the schoolwork that Lowise could develop, even though she was undergoing treatment in hospital. Larissa was referring to the EFL classes Viviane taught to Lowise via Facebook, e-mail, Edmodo, and Skype. Larissa comments that this entire relationship built through the Internet had meant so much to her and Lowise. Larissa said that her daughter, "did not know she knew English," and that she felt important when she was doing the tasks Viviane proposed. She liked being able to have contact with the school, even from a distance; she realized that she could accomplish the tasks, make choices, create, and build knowledge.

When the school decided to fail Lowise in 2015, Larissa fought to prove that the system was wrong, and that it was the school that should prove that her daughter was not able to enter grade 7. Larissa brought the case before the Civil Court. The case was reviewed by the court and the school 
failed to prove that Lowise was unable to attend grade 7, therefore the school's decision to fail her was not upheld.

In addition to being highly emotional, Lowise's story is relevant to the academy and to school contexts, as it presents tensions related to authorial opportunities created (or not) by school, authorship opportunities of students undergoing medical treatment, the understanding that most teachers have about what it is to learn and teach, and the creation of knowledge communities and narrative authorship. Significantly, access to digital technology made this possible for Lowise.

\section{Writing a Story to Live By}

Everton's manner in the computer lab drew our attention. He took a leading role when engaging in class activities. When he helped classmates, he did not readily give the answers. Rather, he gave the other youth the opportunity to speak. He asked questions, showed his classmates how he had carried out his assignment, but did not do their work for them. Everton was engaged in the act of constructing knowledge, rather than transmitting it. Lowise was also constructing knowledge without the presence of the teacher, since she had found an autonomous way to learn and share her findings. They did this in different places related to the classroom through the use of technology.

The inside and outside classroom places are epistemologically and morally different on teachers' professional knowledge landscape (Clandinin \& Connelly, 1995). According to Clandinin and Connelly, living in these two epistemologically different places on the landscape creates dilemmas for the teacher, since within the classroom the teacher finds a safe place to live her stories, created in the relationships with her students. Outside the classroom, in school contexts, the teacher does not feel safe to live and narrate her stories. Murphy (2004) wrote about the inversion of these places for the children; we wonder how Everton and Lowise felt as they were positioned on these two places on the landscape in such different ways in relation to technology. Our consideration of their location on the landscape in relation to school challenged us to consider the complexity of their relationship to school, which was often mediated by technology, and therefore affecting the production of their texts. We wondered if, for Everton and Lowise, there would also be a reversal of places in the landscape in terms of safe and unsafe, as Murphy (2004) suggested, but in a different way: were the virtual spaces where EFL classes took place safe places, where they felt free, capable, and respected?

Viviane shared authority (Oyler, 1996) with Everton and Lowise as they created English-speaking writing spaces in grade 6 . When they felt their experiences were being valued and their voices heard, they began to leave their mark on the school landscape. Everton loved to walk through the computer lab and talk to other classmates, always willing to help them do the assignments. Lowise loved to engage in the EFL activities through Edmodo, Facebook, and Skype, but while she was in the hospital during the school year Lowise only attended Viviane's classes three times in person. All the other activities were developed at a distance using digital technologies. 
We consider the possibility that Everton and Lowise had different school stories to live by in EFL classes because what they did was not what the school validated or allowed. For Everton, this involved standing up and moving around, talking to classmates, collaborating, sharing knowledge, sending stories to his teacher, and posting his assessments on the Internet. For Lowise, it was the delivery of activities through the Internet and not attending classes regularly. Technology for Lowise and Everton shaped a different way of being.

Relationships built on digital landscapes. Everton told us that if he had been more considerate and learned the contents by heart, he would not have failed the previous year. In other words, by demanding from him a reproduction of the subject matter taught, which he was unable to provide, the school had unwittingly stopped Everton's authorship. Lowise thought that if she was not sick and had been able to attend school regularly, she would have been capable of going to grade 7, although some teachers and coordinators thought otherwise. On the other hand, Everton and Lowise said they had more freedom to write in EFL classes. They could show and express what they felt. Freedom, in this case, promoted the possibility of authorship.

As we considered Lowise and Everton's stories, we began to understand that there are different paths of authorship, and the path one follows depends on the lived stories and relationships temporally built on different landscapes. Some of the landscapes where this story took place were the computer lab, the hospital, and the virtual spaces of Facebook, Edmodo, and e-mail. Somehow these places were not part of the school for them, and in this space they could be more themselves and through it they felt a connection to Viviane. Lowise was at the hospital almost every day, but participated through the Internet. Physically, Lowise felt very weak and was not able to go to school. However, despite being in hospital, the digital technologies allowed her to learn and share.

Over time, the landscapes where Everton, Lowise, and Viviane shaped their stories to live by existed in the classroom, the virtual space where they exchanged e-mails, as well as in the computer lab and the school yard. The relationship between Viviane, Lowise, and Everton, in and out of school, helped the children trust her in order to live their experiences of writing, reflecting, and building their personal practical knowledge (Clandinin, Connelly, \& Craig, 1995; Craig, 1995; Murphy, 2004). The teacherstudent relationship is fundamental to the construction of student and teacher stories to live by. Everton and Lowise felt encouraged to continue writing, positioning Viviane as their first reader, then their classmates, and then a bigger audience when they published their texts on the Internet. To validate their stories, Viviane tried to travel to their worlds (Lugones, 1987). She sought to take into account Everton and Lowise's stories to live by, and their personal practical knowledge.

Recalling the criteria of experience (Dewey, 1938), continuity, and interaction, we understand that Everton and Lowise's experiences with digital technologies at the EFL classes were educative, as they moved towards future authoring endeavors. If it had been possible to continue working with these two participants for a few more years, we imagine that they would have built a strong story of authorship, mainly because they had already found their own voice in writing, in addition to leaving their mark on the field of research. 


\section{Conclusions}

When Viviane entered the research field in early 2014, she was seeking to live and understand experiences of authorship in her teaching practice and, in a relational manner, to understand the experiences of authorship experienced by her students, especially on the digital landscapes at Aquarela School. She made attempts at authorship for herself, teaching English using digital technologies, and wondered about the future for herself, Everton, and Lowise. Investigating the stories she shaped with the youth, she realized she was learning to be a different teacher (Murphy \& Bengezen, 2015). Like the youth, she was authoring in technological environments. She was changing her story as a teacher. In contrast to the homogenized stories she had previously experienced as a teacher, she began to think more deeply about the needs of the youth, each in their own specificity, and not perceived by her.

Everton and Lowise helped Viviane understand the stories they were living and authoring. Viviane lived, according to her, successful stories, creating safe spaces and traveling to the worlds of the youth, but she also experienced stories of failure. In understanding these stories as attempts, we are able to point to the transformative character of them, recognizing and imagining future possibilities. As Viviane lived within her teaching experiences, the youth also lived authoring experiences in the English classes. This is the relational aspect of curriculum making: they were all learning together. The experiences alongside the youth, often in relation to technology, helped Viviane share authority with them and create English-speaking writing spaces in the sixth grade. When the youth felt their experiences were being valued and their voices were being heard, they began to make their mark on the school landscape.

Everton loved to walk through the computer lab and talk to classmates, always willing to help them do the assignments. The tensions experienced in Everton's stories were mainly due to the fact that he was a repeating student who was seen by his teachers as a problem. Viviane did not understand how a youth like Everton, who wrote incredible stories, helped his classmates, and was a proficient computer user, could have repeated the year. With him, she learned that the school can prevent authorship, rather than promote it.

Lowise was the author of a profile, an avatar, and a T-shirt slogan, always eager to share who she was and who she was becoming as she moved from hospital to school and family settings. Her mother Larissa was a model of resilience and persistence who never gave up fighting for her hospitalized daughter's right to belong to a knowledge community like a school. With Lowise and Larissa, Viviane learned how to listen to the story of the other and how to validate this story, pay attention to it, show empathy, and deal with vulnerability.

The stories of authorship that Viviane and the children lived were stories of sharing authority, responsibility, community, freedom, protagonism, rereading, signature, negotiation, relationship, ethics, and safe spaces. We can consider these stories as separate events from what Viviane and the youth did together. However, these are also threads in lives and across lives, not stand-alone stories. As Dewey (1938) taught us, every experience shapes future experiences, and is modified by them in return. 
The threads traveled across Viviane and the youth's experiences together. One thread can be found in another thread, and in their weaving together a life is shaped. Our lives can be understood in the relational space of the other. Viviane knows herself as a teacher and a woman in the space she shared with the youth, and it is evident from their work together that the youth understood themselves in part in the space Viviane inhabited.

In this paper we discussed authorship and authority. We see the two related through the ways the authorship of the youth supported their authority over school spaces and their learning. Significantly, technology helped them accomplish this in diverse ways and positioned them in relationship to the school landscape as knowers, as people with authority. Lowise and Everton were not only learning English in a technology-rich environment, but also learning about themselves.

\section{Notes}

1. "Stories to live by" is a narrative term for identity. It takes up a narrative understanding of experience situated along a continuity of life understanding that we are composed of the experiences (stories) that we have lived.

2. During this research, Lowise died from cancer.

\section{References}

Bengezen, V. C. (Org.) (2016). We are the authors. Retrieved from https://www.widbook.com/ebook/brazilian-authorship

Brait, B. (2016). Vozes entre as dobras da autoria. Revista da ABRALIN, 15(2), 53-82.

Bruner, J. S. (1986). Actual minds, possible worlds. Cambridge, MA: Harvard University Press.

Clandinin, D. J. (2013). Engaging in narrative inquiry. Walnut Creek, CA: Left Coast Press, Inc.

Clandinin, D. J., \& Connelly, F. M. (1992). Teacher as curriculum maker. In P. W. Jackson (Ed.), Handbook of research on curriculum (pp. 363-401). New York, NY: Macmillan.

Clandinin, D. J., \& Connelly, F. M. (1995). Teachers' professional knowledge landscapes. New York, NY: Teachers College Press.

Clandinin, D. J., \& Connelly, F. M. (2000). Narrative inquiry: Experience and story in qualitative research. San Francisco, CA: Jossey-Bass.

Clandinin, D. J., \& Connelly, F. M. (2011). Pesquisa narrativa: Experiência e história em pesquisa qualitativa. Uberlândia, Brasil.

Clandinin, D. J., Connelly, F. M., \& Craig, C. (1995). Teachers' professional knowledge landscapes. New York, NY: Teachers College Press.

Clandinin, D. J., Huber, J., Huber, M., Murphy, M. S., Pearce, M., Murray-Orr, A. et al. (2006). Composing diverse identities: Narrative inquiries into the interwoven lives of children and teachers. London: Routledge. 
Clandinin, D. J., \& Murphy, M. S. (2009). Comments on Coulter and Smith: Relational ontological commitments in narrative research. Educational Researcher, 38(8), 598-602.

Clandinin, D. J., \& Rosiek, J. (2007). Mapping a landscape of narrative inquiry: Borderland spaces and tensions. In D. J. Clandinin (Ed.), Handbook of narrative inquiry: Mapping a methodology (pp. 35-75). Thousand Oaks, CA: Sage Publications, Inc.

Clarke, C. (2016). Beyond the muskeg: Poetic expressions of a narrative inquiry into curriculum making and identity making on the edges of community. (Doctoral Dissertation Dissertation/Thesis, Unpublished), University of Saskatchewan, Saskatoon, SK.

Connelly, F. M., \& Clandinin, D. J. (1988). Teachers as curriculum planners: Narratives of experience. New York, NY: Teachers College Press.

Connelly, F. M., \& Clandinin, D. J. (1990). Stories of experience and narrative inquiry. Educational Researcher, 19(5), 2-14. doi:10.3102/0013189x019005002

Connelly, F. M., \& Clandinin, D. J. (2006). Narrative Inquiry. In J. Green, G. Camilli \& P. Elmore (Eds.), Handbook of complementary methods in education research (pp. 477-487). Mahwah, NJ: Lawrence Erlbaum.

Craig, C. (1995). Knowledge communities: A way of making sense of how beginning teachers come to know in their professional knowledge contexts. Curriculum Inquiry, 25(2), 151-175.

Cristóvão, V. L. L., \& Beato-Canato, A. P. M. (2016). A formação de professores de línguas para fins específicos com base em gêneros textuais. DELTA. Documentação de Estudos em Linguística Teórica e Aplicada (Online), v. 32, 45-74.

Dewey, J. (1938). Experience and education. New York, NY: Simon and Schuster Inc.

Fernandes, C. A. (2016). O autor: Morte do homem, nascimento do sujeito. Revista da ABRALIN, 15(2), 19-38.

Lugones, M. (1987). Playfulness, "world"-travelling, and loving perception. Hypatia, 2(2), 3-19.

Minh-ha, T. T. (1989). Woman, native, other: Writing postcoloniality and feminism. Bloomington: Indiana University Press.

Morris, D. B. (2001). Narrative, ethics, and pain: Thinking with stories. Narrative, 9(1), 55-77.

Murphy, M. S. (2004). Understanding children's knowledge: A narrative inquiry into school experiences. (Doctoral Dissertation Dissertation/Thesis, Unpublished), University of Alberta, Edmonton, AB.

Murphy, M. S., \& Bengezen, V. (2015). Learning to co-compose curriculum with youth. Journal of Family Diversity in Education, 1(3), 17-32.

Oyler, C. (1996). Making room for students: Sharing teacher authority in room 104. New York, NY: Teachers College Press.

Possenti, S. (2016). Notas sobre autor. Revista da ABRALIN, 15(2), 219-244.

Schwab, J. J. (1973). The practical 3: Translation into curriculum. The School Review, 81(4), 501-522. 


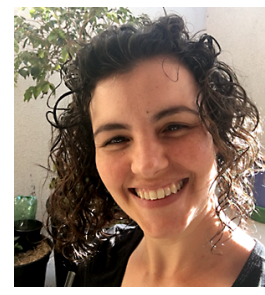

Viviane Cabral Bengezen is an Adjunct Professor at the Federal University of Goiás, in Catalão, Brazil. She is a member of the Narrative Inquiry and Teacher Education Research Group - GPNEP in Brazil. Her PhD was in Applied Linguistics, and, as a researcher, she is interested in stories of authorship that students and teachers live and tell in schools and universities.

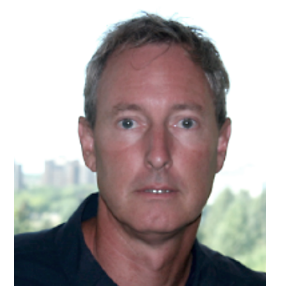

M. Shaun Murphy is Professor in the Department of Educational Foundations at the University of Saskatchewan. He was a classroom teacher for 20 years before making a career move to the university. As a public school teacher, most of his career was spent in the primary grades. He has a keen interest in the lives of children and teachers. His research focuses on relational narrative inquiry with attention to familial and school curriculum making; the interwoven lives of children/youth, families, and teachers; rural education; and teacher education. 
50 | LEARNing Landscapes | Autumn 2017, Vol. 11 No. 1 